\title{
Case Study of Ruqyah Therapy On Muslim Patient with Eczema
}

\author{
Hamidi Abdul Rahman and Supyan Hussin
}

\section{ABSTRACT}

A case study on a female Malay living in the UK with serious eczema was presented. Her parents believed that it was a condition called santau, a common cultural belief in South East Asian countries. Santau is believed as the insertion of poisonous materials into the victim's body with the help of jinn. Santau is normally differentiated from other medical skin conditions by the rapid deterioration of the condition and rapid improvement after successful treatment. Her skin condition was intolerable after a trip to Malaysia. Unable to be admitted to hospital because of the pressure on hospital beds during the Covid-19 pandemic, she resorted to intensive multiple-day ruqyah therapy, a therapy based on the incantation of verses from the Quran. Remarkable improvement was observed after three days. Apart from delivering therapeutic outcome, ruqyah therapy as a Traditional and Complementary Medicine has its role in relieving the pressure on the mainstream health system especially in time of pandemic.

Keywords: Complementary medicine, Jinn possession, Ruqyah, Santau.

\section{INTRODUCTION}

Some cultures experience a pattern of medical conditions that are common within their community but unknown elsewhere. There is normally an accepted explanation within the culture of the cause of the medical condition and associated treatment is normally available within the culture. This case study focuses on treatment of a patient with eczema using an Islamic complementary treatment.

\section{CASE PRESEnTAtion}

The subject is a 21-year old female Muslim of Malay ethnicity and originally from Malaysia but has been living in the United Kingdom since she was six months old. She initially had eczema in October 2019 for two months, a year after her trip to Malaysia. In March 2020 she went for another trip to Malaysia for five months and upon returning to the UK, her eczema started to get worse, affecting every part of her body although she had been using moisturizing lotion for it. In December 2020 her skin condition got extremely bad and watery with extreme itchiness. She was forced to wear loose clothing made of soft and slippery materials and piles of dead skin cells came out every time she went to bed. Her sleep pattern was also disturbed by the extreme itchiness. Her parent called the ambulance when her condition was no longer tolerable, hoping that she would be admitted to hospital. Although the ambulance came, she was not taken to hospital possibly because of the Covid-19
Submitted : January 29, 2021

Published : February 10, 2021

ISSN: 2593-8339

DOI: $10.24018 /$ ejmed.2021.3.1.696

\section{H. A. Rahman*}

Institute of Malay World and Civilization, Universiti Kebangsaan Malaysia, Malaysia.

(e-mail: hamidi@ pisang.uk)

S. Hussin

Faculty of Social Science and Humanities, Universiti Kebangsaan Malaysia, Malaysia.

(e-mail: supyan@ ${ }^{\circledR k m . e d u . m y) ~}$

*Corresponding Author

pandemic and the pressure it exerts on hospital beds.

\section{Cultural EXPLANATION OF ILLNESS}

One of her parents believed that she had been affected by a condition known as santau while she was in Malaysia. Santau is believed to be the insertion of poisonous materials into the victim's body with the help of jinn, commonly referred to as spirits or demons in other cultures. The victim may exhibit various symptoms depending on the type of santau including itchiness or other skin conditions. The belief in the presence of santau is common in South East Asian countries like Malaysia and Indonesia, and there are complementary Islamic therapies that deal with it. A popular therapy in Malaysia is tepuk, which involves the tapping on the victim's back with leaves from the jackfruit tree in order to extract the poison [1]. Quranic verses were read on the leaves before the treatment starts. Santau is unknown outside South East Asia, and for that reason, Middle Eastern or Indo-Pakistan Islamic medical practitioners make no mention of it. Santau is normally differentiated from other medical skin conditions by the rapid deterioration of the condition and the rapid improvement after successful treatment.

In the Islamic faith, jinn can cause diseases and disorders. Jinn is made of invisible matter that is still unknown to science, and jinn has the ability to transform itself to enter human body. Jinns are spiritually similar to human, with freedom of choice, and are accountable for their actions. 
There will be conflicts between the jinn's mind and human mind i.e. inter-psyche conflicts, when a jinn enters a human body. The presence of multiple minds in a single human body can create symptoms. A previous quantitative study on the symptoms of jinn possession have identified 23 significant symptoms and 11 less significant symptoms [2]. The subject had been identified as having seven significant symptoms i.e. seeing things, hearing voices, paranoid, laziness, loss of meaning of life, ill thoughts and crying while asleep. The high number of significant symptoms is an indication that she was very likely to be affected by jinn possession according to the study. The belief in santau as the cause for the eczema prompted the subject's parents to look for Islamic Complementary Therapy.

\section{ADMINISTRATION AND EFFECT OF RUQYAH THERAPY}

Through recommendations by their community, the subject agreed to undergo multiple-day intensive ruqyah therapy. Ruqyah is an Islamic Complementary Therapy through the incantation of selected verses of the Quran, and has become popular in the last decade [3]. The incantations must not contain any polytheistic incantations in order to comply with the Islamic legal system [4]. Various studies have found the therapeutic effects of ruqyah on patients with psychological disorder such as depression [5], [6], [7] as well as some physical ailments [8], [9]. A case study in the UK has also found out that ruqyah had therapeutic effects on a patient with cluster headache, a neurological disorder [10].

A double session of ruqyah was administered on the first day. The subject felt pain throughout her body, and some improvements of her skin condition were observed but her sleep was still disturbed. On the second day, during the second ruqyah session, she experienced excruciating pain, groaned, as well as heavy breathing, and started to talk in Malay. The switch to Malay language was not expected as she had been speaking fully in English since the first day. This was followed by a big bodily jerk. The subject exhibited a calmer personality immediately after the jerk, spoke English again and felt psychologically better. Ruqyah practitioners consider these reactions as indication of jinn possession [2]. Another session of ruqyah was administered later on the day followed by a further three sessions for the following two days but the subject felt calm and did not experience any pain during the sessions. Further improvement was observed, and dead skin cells were no longer coming off her during her sleep. Her skin condition and sleep pattern continued to improve. A psychotherapy session was also conducted, and she had a more positive attitude and looked forward to move on with her life now that her skin condition had greatly improved.

A photograph of her before and on the fifth day after the start of therapy is shown in Error! Reference source not found.. The extend of seriousness of the eczema on the face and neck before therapy can be visually seen and similar conditions were present throughout her body and limbs. The photograph after therapy shows significant improvement and similar improvement was also observed throughout her body.

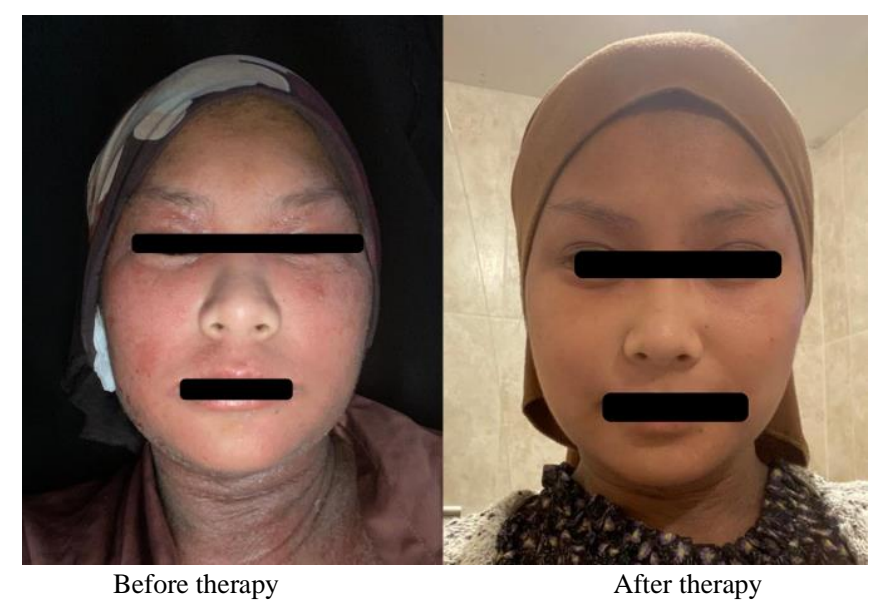

Fig. 1. Skin condition before and after therapy.

\section{DISCUSSION}

The believe in jinn possession and jinn related illnesses in not uncommon in many cultures. ICD-11 described "Possession trance disorder" as a person's identity being replaced by an external "possessing" identity. The "possessing" identity is referred to as the jinn from the Islamic perspective. Cases that defy logic and the laws of physics have been known to happen. In a case study in Indonesia, the surgeon was baffled with the reappearance of new foreign metallic nails a few days after surgical removal of all the foreign items [11].

Extraordinary improvement of the subject's skin condition was observed with 72 hours of the start of the ruqyah therapy. As she had number of symptoms related to jinn possession, the ruqyah practitioner suggested that her eczema may have been caused by toxins produced by the jinn in her body. Assuming the jinn left the body when there was a sudden big bodily jerk, no new toxins were produced, and therefore, her skin condition improved.

The drive to seek Traditional and Complementary Medicine (TCM) in this case is caused by two factors. Firstly, the pressure on available hospital beds caused by the Covid-19 pandemic has resulted in many cases of refusal for hospitalization. This can force those who are desperate for treatment to look elsewhere. The sequence of events has shown that the choice for seeking treatment was not motivated by the rejection of modern medicine. Secondly, the faith in TCM is still embedded in many societies, has survived the test of time and is highly unlike to disappear. TCM have not reached the status of evidence-based medicine but the increasing number of its effectiveness over modern medicine in the treatment of certain diseases and disorders makes it a good candidate for becoming one. The World Health Organization (WHO) acknowledges the importance of TCM and has developed a strategy to support member states to harness the potential of traditional medicine and to promote the safe and effective use of traditional medicine. WHO defines Traditional Medicine as healthcare, which has its own theories and beliefs, and Complementary Medicine as healthcare practices that are not fully integrated into the dominant health-care system [12]. TCM can relief the mainstream healthcare system both during the time of pandemic and in time of normality. This is the case of ruqyah therapy where the theory and beliefs 
are not shared by modern medicine. More studies on ruqyah therapy are needed to identify the nature of diseases or disorders where it works better than modern medicine.

Religious belief as well as effectiveness of the therapy can be a factor as to why TCM will continue to flourish. This is shown in a study in Iraq on 482 patients found that $57 \%$ of them also seek treatment from faith healers while also engaging in psychiatric consultations [13]. TCM is not a substitute for modern medicine. Combining both modern medicine and ruqyah can bring better sustainable therapeutic benefits as shown in a case study on a subject with a major depressive disorder [14]. By providing modern medicine and TCM, patients can have the best of both forms of treatment.

\section{REFERENCES}

[1] D. Haron and K. Mokhtar, Kaedah Merawat Santau. Selangor: PTS Islamika Sdn Bhd, 2013.

[2] H. A. Rahman, M. K. Mokhtar, A. R. Roseliza-Murni, and A. C. Kasim, "Intra and Inter-psyche Conflicts and Analysis of Symptoms of Jinn Possession," Malaysian J. Med. Heal. Sci., vol. 15, no. SUPP1 April 2019, pp. 110-113, 2019.

[3] Y. M. Eneborg, "Ruqya Shariya: Observing the rise of a new faith healing tradition amongst Muslims in east London," Ment. Health. Relig. Cult., vol. 16, no. 10, pp. 1080-1096, Dec. 2013.

[4] A. Khadher, M. A. Ramli, and N. A. A. Rahman, "Pemahaman Terhadap Aspek Penggunaan Ruqyah Dalam Rawatan Penyakit: Analisis Berasaskan Fiqh al-Hadith imam al-Bukhari," Al-Bayan - J. Qur'an Hadith Stud., vol. 14, pp. 168-205, 2016.

[5] M. F. Satrianegara and A. Mallongi, "Influence of self ruqyah treatment on cortisol content, depression, and quality of life, spiritual life quality of cancer patients undergoing radiotherapy in Makassar City, Indonesia," Syst. Rev. Pharm., vol. 11, no. 7, pp. 212-218, 2020.

[6] M. W. Mashitah and K. A. Lenggono, "Quran recitation therapy reduces the depression levels of hemodialysis patients," Int. J. Res. Med. Sci., vol. 8, no. 6, p. 2222, 2020.

[7] M. A. Mohamad and N. Othman, "The Ruqyah Syar'iyyah Spiritual Method As An Alternative For Depression Treatment," Life Sci. J., vol. 14, no. 2, pp. 75-80, 2017.

[8] Adynata and Idris, "Effectiveness Of Ruqyah Syar'iyyah On Physical Disease Treatment In Riau Province," J. Ushuluddin, vol. 24, no. 2, pp. 211-233, 2016.

[9] S. Hussin, N. A. A. Rahman, L. K. On, and M. K. Mokhtar, "Bridging Modern Medicine with Islamic Complementary Medicine: Preliminary Attempts in Malaysian Context," Adv. Sci. Lett., vol. 24, pp. 4820-4823, 2018.

[10] H. A. Rahman and S. Hussin, "Case Study of Using Ruqyah Complementary Therapy on a British Muslim Patient with Cluster Headache," Eur. J. Med. Heal. Sci., vol. 3, no. 1, pp. 5-7, 2021.

[11] N. A. Rahman, S. Sukardi, and S. Husin, "A Case Study of Modern Medical Practice and Islamic Complementary Therapy on a Patient with Over 2000 Embedded Nails," Int. J. Public Heal. Sci., vol. 4, no. 4, pp. 310-314, 2015.

[12] WHO, WHO Traditional Medicine Strategy 2014-2023. 2013.

[13] M. S. Younis, R. K. Lafta, and S. Dhiaa, "Faith healers are taking over the role of psychiatrists in Iraq," Qatar Med. J., vol. 2019, no. 3, pp. 1-8, 2019.

[14] Z. A. Razali, N. A. A. Rahman, and S. Husin, "Complementing the treatment of a major depressive disorder patient with Ruqyah Shar'iyyah therapy: A Malaysian case study," J. Muslim Ment. Health, vol. 12, no. 2, 2018.S. Chen, B. Mulgrew, and P. M. Grant, "A clustering technique for digital communications channel equalization using radial basis function networks," IEEE Trans. on Neural Networks, vol. 4, pp. 570-578, July 1993.
Rahman H. A. obtained an MSc in Psychotherapy Studies from the University of Sheffield, United Kingdom in 2013. He is currently pursuing his $\mathrm{PhD}$ at the Institute of Malay World and Civilization, Universiti Kebangsaan Malaysia, Malaysia. He is also the CHAIRMAN of PISANG, a not-for-profit organization in the United Kingdom specializing in the treatment and research on jinn possession.

Hussin S. obtained his $\mathrm{PhD}$ (Education) from University of Illinois Urbana-Champaign. Currently, he serves as a professor at the Faculty of Social Science and Humanities, Universiti Kebangsaan Malaysia, and an Associate Research Fellow at the Institute of Malay World and Civilization, Universiti Kebangsaan Malaysia. He is the President of Charity Association of the Ethnological-Medical Science of the Malay World and Complementary Malaysia. 